\title{
On the Unmarked Position for Greek Subjects: Problematic Issues and Implications for Constituent Order*
}

\author{
George Kotzoglou \\ University of the Aegean \\ gkotz@rhodes.aegean.gr
}

\begin{abstract}
This paper examines the position of preverbal subject in Greek $\mathrm{SV}(\mathrm{O})$ orders. Using interpretational and configurational evidence we confirm the conclusion of much of the standard literature that preverbal subjects in Greek do not occupy the [Spec, TP] position, but are left dislocated elements. In particular, we discuss the proposals of Roussou \& Tsimpli (2006) and Spyropoulos \& Revithiadou $(2007,2009)$, who argue for the existence of an A-subject in the Greek T-domain, and we point out a number of counterarguments to their suggestions. Finally, we tentatively suggest that the $\mathrm{EPP}_{\mathrm{T}}$-requirement might be suspended in Greek.
\end{abstract}

\section{Keywords}

syntax; Greek; subject; Extended Projection Principle (EPP); word order; SV(O)

\section{Introduction}

One of the most well-known research results of the Principles and Parameters literature on Greek word order and the Greek A-system has been the conclusion that Greek DP-subjects never raise to the 'canonical' $\mathrm{EPP}_{\mathrm{T}-\text { position }}{ }^{1}$

\footnotetext{
"I would like to thank Vassilios Spyropoulos, Michalis Georgiafentis and two anonymous reviewers for helpful comments and discussion. Errors and misunderstandings are my own, of course.

1) The Extended Projection Principle (EPP) was posited by Chomsky (1981) as the requirement that every clause has a subject. As such, through the literature of the 1980s and 1990s the EPP refers to the requirement that the [Spec, IP]/[Spec, TP] position be filled through the course of the derivation. However, research originating in Chomsky $(2000,2001)$ views the EPP as a feature on syntactic heads which triggers merge to their specifier. Hence the convention of subscripting 'EPP' with the label of the head of which the EPP-feature belongs to $\left(\mathrm{EPP}_{\mathrm{T}}\right)$. In what follows, we will be discussing the nature of the EPP-feature of T (and, ultimately, question its existence) and, hence, we will be concerned with the somewhat 'traditional' notion of EPP (but see section 5 on alternative accounts of the EPP). As a consequence, we will be using the terms $\mathrm{EPP}_{\mathrm{T}}$-position and [Spec, TP] position interchangeably.
} 
(cf. Philippaki-Warburton 1987; Alexiadou \& Anagnostopoulou 1998, 1999; Spyropoulos 1999; among many others). The claim for the unavailability of [Spec, $\mathrm{TP}$ (former [Spec, IP]) to subjects (and everything else) was based on a number of diagnostics, both interpretive and configurational ones (e.g. the oddness/ungrammaticality of a number of readings in SVO orders, the obligatorily wide scope of the subject with respect to sentential negation, the lack of inverse scope interpretation in SVO, the phonological attachment properties and positioning of preverbal particles). The acknowledgement of the unavailability of [Spec, TP] as a landing site for surface subjects lent support to the proposal that the syntactically least marked word order in Greek is the VSO order, since this was the only order that was produced exclusively with obligatory operations (namely, V-to-T head movement), a claim initially put forth in Philippaki-Warburton (1982) and later defended in Philippaki-Warburton (1985, 1987) and subsequent work. Ever since, the standard assumption has been that a) preverbal subjects in Greek are (clitic-)left-dislocated elements, and, therefore, the $\mathrm{SV}(\mathrm{O})$ order is derivative and marked, while b) $\mathrm{VS}(\mathrm{O})$ may be obtained with all verbal arguments in situ (cf. Alexiadou \& Anagnostopoulou 2001) and, hence, it involves the minimum amount of 'extra' or costly syntactic operations (presumably none at all).

However, a number of current works on the distribution and interpretation of Greek subjects challenge this argument. First of all, the unavailability of the $\mathrm{EPP}_{\mathrm{T}}$-position to subjects in Greek is far from being taken for granted. Sifaki $(2003,2004)$ claims that a number of different elements (including subjects in normal SVO) may be raised to [Spec, TP]. ${ }^{2}$ Spyropoulos \& Revithiadou (2007, 2009) argue that Greek subjects do raise to [Spec, TP] and that the interpretive intricacies of the different word order permutations (especially as regards the VS/SV distinction) as well as the distribution of the overt subject itself reduce to spell-out preferences at the interfaces, as expected within a single-output model of syntax (in the sense of Bošković 2001; Bobaljik 2002). What is more, Roussou \& Tsimpli (2006) argue that preverbal argumental positions for subjects (among others) are available in the $d_{\mathrm{T}}$ (their Tense-domain).

This paper brings together and reviews some notable configurational and interpretive properties of the structures in question, and argues against these approaches. More specifically, a) we claim that Greek preverbal subjects necessarily occupy non-A/non-EPP ${ }_{\mathrm{T}}$ positions, and $\mathrm{b}$ ) we confirm once again that Greek can manifest a VS(O) with the subject in situ (while we do not preclude the possibility of alternative derivations of VS(O), too). First, it is shown that the

2) Actually, [Spec, IP] in Sifaki's system. 
presence of a copy of the subject in [Spec, TP] creates both configurational and linearization problems, as it should interfere both with T-oriented special clitics and their binding properties (an issue discussed in Horrocks 1994, Spyropoulos 1999, Panagiotidis \& Tsiplakou 2006) and with the phonologically dependent preverbal particles. Secondly, we show that a number of interpretational properties that according to Roussou \& Tsimpli (2006) should be attributed to subjects that occupy $d_{\mathrm{T}}$ (akin to, we assume, [Spec, TP] in other approaches), valid though they may be, do not single out a position configurationally close to $\mathrm{T}$, as the same set of interpretations can be given to subjects that are found in the left periphery of the clause (the $d_{\mathrm{C}}$ ), nor need these interpretations be exclusively attributed to moved material such as derived subjects (in fact, it will be shown that according to some diagnostics even base-generated phrases may be given similar readings). What is more, evidence is adduced to the effect that postverbal subjects may remain $\nu \mathrm{P}$-internal and that there is no need to postulate the existence of distinct A-positions above $\nu \mathrm{P}$ as landing sites for postverbal material.

The acknowledgement of the fact that the postulation of derivative A-positions for subjects in Greek is not tenable (at least not for [Spec, TP]) brings to the fore the question of the way the EPP-feature of $\mathrm{T}\left(\mathrm{EPP}_{\mathrm{T}}\right)$ is checked in this language. We discuss Alexiadou \& Anagnostopoulou's (1998) argument that $\mathrm{EPP}_{\mathrm{T}}$-feature in Greek is checked by means of $\mathrm{V}$-movement to $\mathrm{T}$ and point to a couple of problems for such an approach. We, then, put forth the claim that the $\mathrm{EPP}_{\mathrm{T}}$ requirement is suspended in Greek (a conclusion that may extend to other null subject languages as well). As a consequence, we propose that the positioning of DP-arguments in $\nu$ P-external positions in Greek is due to discourserelated requirements and, therefore, orders other than VSO are indeed syntactically marked, thus confirming the leading intuition behind much of the research of the 1980 and 1990 s.

This article is structured as follows: Section 2 provides the necessary background on the significance of the position of the subject (and the nature of the $\mathrm{EPP}_{\mathrm{T}}$ ) to the discussion of the basic order of constituents in Greek. Section 3 examines the issue of the configurational position of preverbal subjects in Greek. Section 4 argues that in Greek VS(O) orders the subject may retain its thematic, base-generated position. Section 5 explores the possibility that no checking of the $\mathrm{EPP}_{\mathrm{T}}$-feature is required in Greek. Section 6 concludes our discussion by examining the implications of the conclusions reached for the recognition of the 'basic' word order. 


\section{Word Order Permutations in Greek-The Importance of the Position of the Overt Subject}

A vast number of studies have addressed the issue of the derivation of the different word order permutations and their associated interpretations in (Modern) Greek (Philippaki-Warburton 1985, 1987, 1989; Drachman 1985; Lascaratou 1989, 1994, 1998; Drachman \& Klidi 1992; Horrocks 1994; Tsimpli 1990; Tzanidaki 1995; Alexiadou 1996; Alexiadou \& Anagnostopoulou 1998, 1999; Spyropoulos 1999; Spyropoulos \& Philippaki-Warburton 2001; Keller \& Alexopoulou 2001; Georgiafentis 2001, 2004; Sifaki 2003, 2004; Roussou \& Tsimpli 2006; Lascaratou \& Georgiafentis 2006, Spyropoulos \& Revithiadou 2007, 2009, among many others). As is well-known, Greek exhibits all six possible orders of the main constituents of the clause (see Lascaratou 1998; Georgiafentis 2004; and Lascaratou \& Georgiafentis 2006 for recent comprehensive overviews), with SV $(\mathrm{O})$ being the predominant one in terms of statistic frequency of occurrence (cf. the corpus-based study of Lascaratou 1989, where the reader is referred to for precise quantitative evidence). We shall not discuss the intricate details of those studies here. The purpose of the present paper is to provide evidence from syntax for the recognition of the basic (or syntactically less marked) word order in Greek.

The discussion on the 'basic' word order in Greek was opened up by Philippaki-Warburton (1982, 1985), who refuted Greenberg's (1963) classification of Greek as a SVO language and argued that the predominant word order in Greek is the $\mathrm{VS}(\mathrm{O})$ one, as this word order a) is used quite frequently by speakers (especially in the absence of an object, the VS orders are comparable in frequency to SV ones, as noted in Lascaratou 1989: 105), b) can be used in contexts where the $\mathrm{SV}(\mathrm{O})$ is dispreferred, such as in embedded subjunctives (1),

(1) a. o petros $\theta$ na kerðisi i omaða tu

the Peter-nom want-non.past-3sg SUBJ win-non.past-3sg. the team-nom his

to kipelo

the cup-acc

'Peter wants his team to win the cup.'

b. ?o petros $\theta$ eli i omaða tu na kerðisi

the Peter-nom want-non.past-r3g the team-nom his SUBJ win-non.past-3sg.

to kipelo

the cup-acc

'Peter wants his team to win the cup.'

and hence it is the most unmarked word order, and c) it can be derived by the minimum amount of syntactic operations. 
Given that the difference of the two main candidates for the 'basic' word order in Greek (SVO and VSO) mainly lies on the ordering of the subject with respect to the verb (which obligatorily raises as far at the T head in Greek) it is no wonder that argument (c), concerning syntactic simplicity, soon got closely related to the issue of the position of the subject in Greek. Greek, as a null subject language, is exempt from the requirement of projecting an overt subject in the preverbal (or, postverbal, for that matter) position and it exhibits the full set of properties that constitute Rizzi's (1982) pro-cluster, namely it permits pro-drop, it exhibits affirmative VS orders and it allows that-trace sequences.

Philippaki-Warburton's (1987) claim that the 'canonical' $\mathrm{EPP}_{\mathrm{T}} /[\mathrm{Spec}, \mathrm{TP}]$ position is not projected in Greek, due to the fact that identification of the subject is achieved through the rich verbal morphology, constituted a firm argument in favour of the postulation of VSO as the basic order in Greek. If indeed a canonical preverbal position for subjects is never projected, then all SV orders in Greek involve a subject fronted for discourse-related reasons, hence the pragmatic markedness of S-initial orders in Greek. Thus, VS-orders are derived through obligatory $\mathrm{V}$-movement to $\mathrm{T}$ (with the subject remaining in its $\nu \mathrm{P}$-internal base position), while SV-orders involve extra operations, such as the base generation of the subject in a left-peripheral clausal position plus the coindexation with an argumental pro in the thematic position:

(2) a. $\left[\mathrm{TP}[\mathrm{T} \mathrm{V}-\mathrm{T}]\left[{ }_{\mathrm{rp}}\right.\right.$ subject $\left.\left.[\mathrm{vP} \mathrm{V}]\right]\right] \quad \mathrm{VS}$

b. subject $t_{\mathrm{i}} \ldots\left[{ }_{\mathrm{TP}} \varnothing[\mathrm{T} \mathrm{V}-\mathrm{T}]\left[{ }_{\nu \mathrm{P}} \operatorname{pro}_{\mathrm{i}}[\mathrm{VP} \mathrm{V}]\right]\right] \mathrm{SV}$

In a similar fashion, Alexiadou \& Anagnostopoulou $(1998,1999)$ provide comprehensive evidence for the claim that the [Spec, TP] position of null subject languages remains blank. Firstly, they observe that existential preverbal subjects obligatorily take wide scope with respect to universally quantified objects, while postverbal subjects are amenable to both scope readings:

(3) a. enas astinomikos sinelave kaقe listi

a policeman-nom arrest-past-3sg every thief-acc

'A policeman arrested every thief.'

a > every, *every > a

b. sinelave enas astinomikos ka $\mathrm{e}$ listi arrest-past-3sg a policeman-nom every thief-acc

'A policeman arrested every thief.'

a $>$ every, every $>$ a

The contrast in (3) cannot be explained if the preverbal subject position is one derived via A-movement, since if this were the case, the fronted subject would be able to reconstruct to a lower position in the scope of the Q-raised object (cf. the discussion in Johnson \& Tomioka 1998). However, Roussou \& Tsimpli 
(2006) challenge Alexiadou \& Anagnostopoulou's (1998) judgments for (3a), arguing that the wide scope reading for the subject in this sentence is merely the preferred one but not the only one and claim that a narrow scope reading for preverbal subjects is also possible. Spyropoulos \& Revithiadou (2007, 2009) share their judgment. As the correct interpretation of the data in (3) hinge on subtle and conflicting grammaticality judgments (I share Alexiadou \& Anagnostopoulou's 1998 judgment for cases like (3a)), I shall not consider (the lack of) inverse scope as conclusive evidence in favour of either approach.

Alexiadou \& Anagnostopoulou (1998) further observe that preverbal subjects in Greek take obligatorily wide scope with respect to sentential negation, while postverbal subjects might take narrow scope as well. Again, the unavailability of narrow scope interpretation for the preverbal subject can be attributed to the fact that in no part of the derivation did this subject occupy a low syntactic position, i.e. the preverbal subject gets externally merged in its surface, leftdislocated position.

$\begin{array}{lllll}\text { (4) a. poli maӨites den etroyan feta } \\ \text { many pupils-nom NEG } & \text { eat-past-3pl feta.cheese-acc }\end{array}$

'Many pupils did not eat feta cheese.'

many $>$ neg, *neg > many

b. ðen etroyan poli maӨites feta

NEG eat-past-3pl many pupils-nom feta.cheese-acc

'Many pupils did not eat feta cheese.' and

'Not many pupils ate feta cheese.'

many $>$ neg, neg $>$ many

Given the impact of the studies of Philippaki-Warburton $(1985,1987)$ and Alexiadou \& Anagnostopoulou (1998) in the Greek literature, it is not far from true to assume that much of the syntactic research of the past two decades on Greek was carried out under the premise that indeed VSO is the 'basic'/unmarked word order and that SVO involves a base-generated topicalized subject, which cannot be assumed to occupy the [Spec, TP] position.

However, a number of recent studies have questioned this conclusion: Roussou \& Tsimpli (2006) argue that a number of semantic interpretations that are incompatible with a topicalized reading (or are associated with the Thead) can be assigned to Greek preverbal subjects. Thus, they observe that the preverbal position can be occupied by subjects of stative verbs ( 5 a), generic subjects $(5 \mathrm{~b})$, $(5 \mathrm{c})$ or subjects of middle constructions, which receive a generic interpretation (5d).

(5) a. i fititria kseri tin apandisi the student-nom know-non.past-3sg the answer-acc

'The student knows the answer.' 


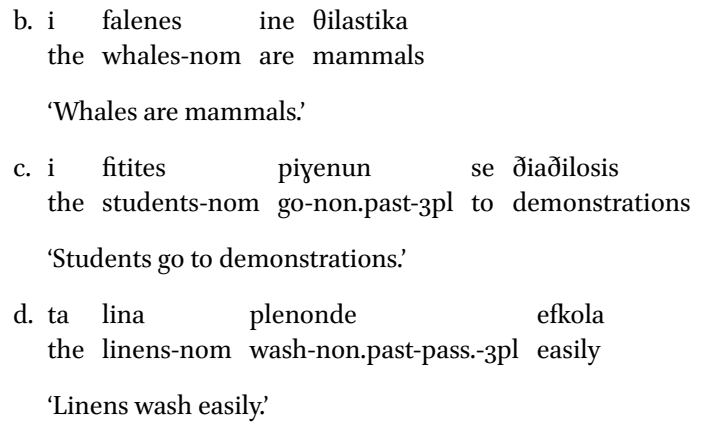

(All examples in (5) from Roussou \& Tsimpli 2006: 340)

In corresponding VS-orders, the inverted subjects cannot retain the stative or the generic readings. Roussou \& Tsimpli (2006) follow Carlson (1977) and Diesing (1992) in assuming that genericity and stativity is tied to the tense properties of the clause. The conclusion reached is that a preverbal position in the $d_{\mathrm{T}}$ (domain of Tense) $)^{3}$ is available to subjects in Greek:

(6) $\quad[\mathrm{CP} C[$ cll subject $][$ Tр … ]]

Another approach which seeks to retain the $[\mathrm{Spec}, \mathrm{TP}] / \mathrm{EPP}_{\mathrm{T}}-$ position in Greek has been put forth by Spyropoulos \& Revithiadou $(2007,2009)$, who argue that the [Spec, TP] position is filled by the raised subject in the course of a derivation in pretty much the same way as in English and other non-pro-drop languages. VS-orders in Greek, according to the authors, involve regular subject movement to [Spec, TP], as SV-orders do, but they amount to spell-out of the $\nu$ P-internal copy of the subject at PF. Spyropoulos \& Revithiadou $(2007,2009)$ adopt Roussou \& Tsimpli's (2006) arguments presented in (5) and proceed to devise tests which show that preverbal subjects prosodify as arguments and not as left-dislocated elements. The authors argue that in narrow syntax Greek subjects obligatorily move to [Spec, TP], thus forming a chain (of at least two copies):

(7) $\quad\left[\mathrm{TP}\right.$ subject $\left[{ }_{\mathrm{T}} \mathrm{V}-\mathrm{T}\right]\left[{ }_{\mathrm{vP}}\right.$ subject $\left.]\right]$

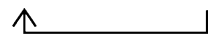

3) Roussou \& Tsimpli's (2006) system comprises a set of clitic projections that may host arguments. These projections are situated on the three major clausal domains: the verbal domain $\left(d_{\mathrm{V}}\right)$, the Tense domain $\left(d_{\mathrm{T}}\right)$ and the Complementizer domain $\left(d_{\mathrm{C}}\right)$. The placement of an argument in each of these domains gives rise to an associated interpretation. 
Spyropoulos \& Revithiadou adopt a single-output model of syntactic derivation in the sense of Bošković (2001), Bobaljik (2002), in which narrow syntax makes available a number of different copies of the moved element and the interfaces (PF and LF) privilege one of those copies (possibly a different one for each interface) for phonological spell-out and semantic interpretation. Then, the difference between SV and VS orders (all other things being equal) may amount to the structures in (8), as possible PF renderings of the narrowsyntactic derivation $(7):^{4}$

(8) a. [TP subject $\left[{ }_{\mathrm{T}} \mathrm{V}-\mathrm{T}\right]\left[{ }_{\nu \mathrm{P}}\right.$ subject $\left.]\right]$
SV
b. $\left[{ }_{\mathrm{TP}}\right.$ subject $\left[{ }_{\mathrm{T}} \mathrm{V}-\mathrm{T}\right]\left[{ }_{\nu \mathrm{P}}\right.$ subject $\left.]\right]$

Finally, Sifaki $(2003,2004)$ argues that $\mathrm{EPP}_{\mathrm{T}}$-feature comprises both a [D]-feature (in the sense of Chomsky 1995) and a [P]-feature. The latter feature is a phonetic requirement that the Specifier of TP(/IP) gets filled by overt material (an idea already explored in Holmberg 2000). I do not go through here the derivations of the different word orders in Sifaki's system (some of which involve piedpiping of large chunks of the syntactic tree to [Spec, TP/IP]), as what is crucial for our purposes is that Sifaki's analysis permits regular movement of the subject to $[$ Spec, TP/IP] in non-focused SVO orders.

As is obvious, the question of the way in which the $\mathrm{EPP}_{\mathrm{T}}$-requirement is satisfied is central to the discussion of the most unmarked (/syntactically basic) word order in Greek. If the above-mentioned recent studies are correct, then the [Spec, TP] position (or an argumental position in $d_{\mathrm{T}}$ ) are available to preverbal Greek subjects and, therefore, regular A-movement can bring DP-internal material to [Spec, TP] (or, whatever the canonical preverbal subject A-position is). If, on the contrary, no preverbal A-position is projected, then SVO orders serve discourse-related functions and, hence, VSO is the syntactically simpler word order in Greek. However, for the latter proposal to be maintained we also need to show that VSO does not involve movement of the subject to a possible derived postverbal position (cf. Belletti $2004^{5}$ ), or else its derivation would be equally costly.

\footnotetext{
4) We adopt the (by now standard) convention of representing phonetically silenced copies in strikethrough font.

5) Roussou \& Tsimpli (2006) also argue that postverbal arguments occupy dedicated phrasal specifier positions in the post-TP area, but, given their proposal that the arguments are 'merged' there and that those projections are associated with thematic and aspectual information, those positions seem to be more of the 'first-merge'/thematic-type.
} 


\section{On the Position of Greek Preverbal Subjects}

\subsection{On the Availability of Non-EPP $P_{T}$ Sites}

The fact that Greek subjects may appear in discourse-related non-A- (and not $\mathrm{EPP}_{\mathrm{T}^{-}}$) positions has been a virtually uncontroversial in the literature. The major argument for such a conclusion is derived by the free positioning possibilities of preverbal subjects, which would not be expected if a requirement on Spec-Head relation, such as the one imposed by traditional conceptions of EPP, applied. Thus, no strict linear adjacency between the subject and the verb is required in Greek. In fact, a number of elements of the left periphery of the clause may intervene between the two. For example, the S-V sequence may be interrupted by left peripheral adjuncts (9a), preverbal particles $(9 \mathrm{~b}),{ }^{6}$ clitic-left dislocated constituents (9c), wh-fronted phrases (9d), or even the embedded C (9e) (Philippaki-Warburton 1985, 1987; Alexiadou \& Anagnostopoulou 1998, 1999).

(9) a. o papus kaӨe mera me meyali ipomoni mas afiyite the grandfather every day with big patience us-gen narrate-non.past-3sg

tis istories tu

the stories-acc his

'Every day, grandpa narrates his stories to us with great patience.'

b. i mitera den $\theta$ a boresi na parakolu $\theta$ isi tin the mother-nom NEG MOD be.able-non.past-3sg SUBJ watch the

tenia stin tileorasi

film-acc in.the television-acc

'Mother won't be able to watch the film on TV.'

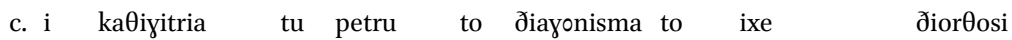
the professor-nom the Peter-gen the exam-acc it-acc have-past.-3sg corrected

apo xtes

from yesterday

'Peter's professor had corrected the exam yesterday.'

d. o skilos mas to FILETO troi oxi tis bananes the dog-nom our-gen the steak-acc eat-non.past-3sg not the bananas-acc

'It's the steak that our dog is eating, not the bananas.'

6) As an anonymous reviewer observes, it might be argued that preverbal particles are merely inflectional heads and, as such, their position is not relevant for adjacency, However, in section 3.2.2 we provide evidence to the conclusion that are independent heads (cf. also PhilippakiWarburton 1998). 
e. i ðaskala pisteve i matites oti $\theta$ a evriskan tin the teacher-nom believe-past-3sg the pupils-nom that MOD find-past-3pl the

askisi ekseretika ðiskoli

exercise-acc exceptionally difficult-acc

'The teacher thought that the students would consider the exercise exceptionally diffcult.'

The fact that material belonging to the C-domain of the clause may disrupt the subject-verb sequence has been taken as conclusive evidence that preverbal subjects may appear in C-related positions or (alternatively) be base-generated in adjoined positions quite far from the 'canonical' $\mathrm{EPP}_{\mathrm{T}}$-one.

Anticipating discussion in section 5 , we observe, however, that the lack of linear adjacency between the Subject and the T head evidenced in (9) does not in and of itself preclude the possibility that the position that the subject occupies in those structures is an A-position (in whatever way one might reinterpret the A-A' distinction in the minimalist framework ${ }^{7}$ ) or that EPP- $/ \varphi$-feature related movement of the subject to a peripheral position might exist. In other words, a reformulation of standard phrase structure could be give rise to a derivation where $\mathrm{T}$ checks its $\varphi$-features with the $\nu \mathrm{P}$-internal subject via long-distance Agree (in Chomsky's 2000, 2001, et seq. system) but transmits its $\mathrm{EPP}_{\mathrm{T}}$-feature to superordinate heads, thus enabling A-movement of the subject to a distant Spec. However, such a proposal would require justification on independent grounds for the claim that such a percolation of the $\mathrm{EPP}_{\mathrm{T}}$-feature is indeed possible and would need to overcome the conceptual problem of accounting for the dissociation of $\mathrm{EPP}_{\mathrm{T}}$-satisfaction and $\varphi$-feature checking, which underlies most explanations of the pro-drop phenomenon as a side-effect of the richness of verbal inflectional paradigms.

Equally problematic would be a proposal that follows Chomsky (2008) and subsequent work (cf. Richards 2007) in assuming that the $\mathrm{EPP}_{\mathrm{T}}$-feature is inherited to $\mathrm{T}$ by $\mathrm{C}$. It might be argued that in Greek (and other null subject languages featuring peripheral subjects) the feature gets inherited not to $\mathrm{T}$, but to an intermediate head, which would then trigger A-movement of the subject to its specifier. Such an approach might work in languages where the C-T sequence

\footnotetext{
7) Throughout this paper we take the $\mathrm{A} / \mathrm{A}^{\prime}$ distinction to be a meaningful one, although we are fully aware of the fact that the justification of this divide remains without a proper theoretical formulation within the minimalist program. However, the empirical data distinguishing between the two (differences in the availability of reconstruction sites, in the creation of new binding configurations, in the relativization of movement blocking etc.) remain valid. We will continue to use the dichotomy, then, in the well-established sense it has within the Principles and Parameters literature.
} 
of heads is virtually uninterrupted by intervening functional heads with overt morphological realization, but it is difficult to be even stated for Greek, where the site hosting the subject in (9) and T, the head bearing the verbal morphology, are too far from each other. Note, also, that it is not only the EPP feature that gets inherited in Chomsky's system, but also $\varphi$-features. Since $\varphi$-features are ostensibly manifested on T, any account claiming that EPP (in the traditional $\mathrm{EPP}_{\mathrm{T}}$-sense) becomes a property of a distinct head needs independent justification.

As far as I am aware, no such proposals have been put forth in the Greek literature. In what follows, then, we will assume that the grammaticality of the $[S$-left peripheral material $-T]$ sequence observed in Greek leads to the conclusion that non-A-related preverbal subjects exist in Greek.

\subsection{On Subjects (or Subject Clitics) on $E P P_{T}$}

Let us now turn to the discussion of whether the [Spec, TP] position is projected in Greek. As already mentioned in previous sections, Philippaki-Warburton (1987) and Alexiadou \& Anagnostopoulou $(1998,1999)$ provide a host of arguments against this claim. This subsection indicates some further problems that recent proposals for [Spec, TP] (or T-related) preverbal subjects in Greek need to overcome.

\subsubsection{Principle C Effects in Cliticization}

A first major argument against the existence of a DP subject (or event a silent copy thereof) in [Spec, TP] can be drawn from the pattern of binding effects involving special clitics, an asymmetry initially observed by Horrocks (1994) and extensively discussed in works by Tsiplakou $(1998,1999)$, Spyropoulos (1999), Spyropoulos \& Philippaki-Warburton (2001), and Panagiotidis \& Tsiplakou (2006).

The argument is based on the observation that the DP-complement of a postverbal subject may not be coreferential with a pronominal special clitic. ${ }^{8}$ No such restriction holds for the complement of a preverbal subject.
(10) a. tin $^{*}$ ijj ayapai
[i mitera [tis marias $\left.]_{i}\right]$
her love-non.past-3sg the mother-nom the Mary-gen
'Mary's mother loves her.'

\footnotetext{
8) Pronominal clitics in Greek occupy a T-related position. Due to their clitic nature, they end up phonologically attached to the verb in $\mathrm{T}$.
} 


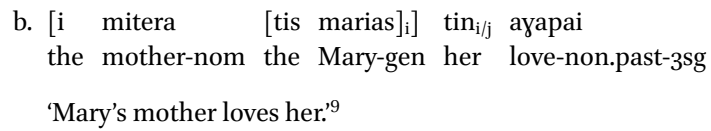

The correct interpretation of the above asymmetry depends, to a large extent, a) on the exact formulation of the binding theory that one adopts (especially with respect to the level of representation where the binding theory applies, cf. Lebeaux 2000, 2009) and b) on the version of clitic-movement one adopts (more specifically, with respect to the position wherefrom the clitic acts as a binder, cf. the discussion in Panagiotidis 2002; Philippaki-Warburton et al. 2004; Mavrogiorgos 2009). We do not take sides on either debate here. We will confine ourselves to showing that whichever analysis one adopts, the contrast in (10a-10b) militates against the conclusion that [Spec, TP] is occupied by a raised subject.

i) If Principle $\mathrm{C}$ of the binding theory applies to all levels of representation (that is, in narrow syntax as well as in LF) (Lebeaux 2009), or, alternatively, if all copies of movement are visible for binding considerations (which amounts more or less to the same thing), then no matter what the position of the moved clitic is, the grammaticality of (1ob) comes as a surprise. In such a case, even normal SVO structures should be ruled out, if they involve a raised subject, as they are produced by A-movement of the subject to [Spec, TP] and contain a full copy of the moved DP in the $v$ P-internal, thematic position, that is, in the scope of the clitic. In other words, the LF representation of both (10a,b) should look like (11). All copies should be visible to LF as chain reduction (phonetic deletion of non-spelled out copies) is a PF mechanism (Nunes 1999):

(11) $\left[\mathrm{TP}\left[\mathrm{i}\right.\right.$ mitera $\left.[\text { tis marias }]_{\mathrm{i}}\right] \operatorname{tin}_{\mathrm{i}}$ ayapai $\left[{ }_{\nu \mathrm{P}}[\mathrm{i} \text { mitera [tis marias }]_{\mathrm{i}}\right]$ ayapai [vp ayapai $\left.\left.\left.\operatorname{tin}_{\mathrm{i}}\right]\right]\right]$

We conclude that under a 'traditional' view in which the binding theory applies at all levels (or, alternatively, all movement copies remain visible at LF and, hence, are all relevant for binding purposes) the claim that preverbal subjects have been moved to their surface position ([Spec, TP] or otherwise) from the thematic one falls short of explaining the facts (a conclusion reached in Panagiotidis \& Tsiplakou 2006).

ii) If the position from which the clitic acts as a binder is higher than [Spec, TP] (i.e. if the clitic occupies the position of an A-specifier between the site of the preverbal particles and TP-as analyzed by Sportiche 1999, see also

\footnotetext{
9) According to Horrocks (1994), (10b) deserves a \%-judgment, an opinion adopted by Spyropoulos (1999) and Spyropoulos \& Philippaki-Warburton (2001). However, neither we and our informants nor Panagiotidis \& Tsiplakou (2006) (seem to) share this judgment.
} 
Anagnostopoulou 1994) or if the clitic can bind from its adjoined position on $\mathrm{T}$ (Philippaki-Warburton \& Spyropoulos 1999, Philippaki-Warburton et al. 2004), then again the subject is in the scope of the clitic both in its thematic and in its derived position. Again, we would expect both VS and SV orders to be ungrammatical in the coindexed reading, contrary to facts, as even the higher complement of the [Spec, TP]-copy would be bound by the clitic.

iii) The only way in which the contrast in (10) might support the claim for A-movement of the subject in [Spec, TP] would be if we considered that Principle C applies only at LF (Chomsky 1995) and both of the following conditions apply: (a) the interfaces can choose only one of the copies of a moved element for interpretation, ignoring the rest, and (b) the A-position from which the clitic acts as a binder is situated lower than [Spec, TP] (presumably in the position of a peripheral, movement-generated Spec of $\nu \mathrm{P}$, cf. the analyses of Panagiotidis 2002; Mavrogiorgos 2009). Then, (10a) and (10b) would be assigned different LF representations:

(12) a. $\left[\operatorname{Tp}^{2}\right.$ ayapai $\operatorname{tin}_{\mathrm{i}}\left[v \mathrm{P}\left[\mathrm{i}\right.\right.$ mitera $\left.\left.\left.[\text { tis marias }]_{\mathrm{i}}\right][\mathrm{vP}]\right]\right]$

(rough LF representation of 10 a under iii)

b. $\left[\mathrm{TP}[\mathrm{i} \text { mitera [tis marias }]_{\mathrm{i}}\right] \operatorname{tin}_{\mathrm{i}}$ ayapai $\left.\left[{ }_{\nu \mathrm{P}}[\mathrm{vP}]\right]\right]$

(rough LF representation of 10 b under iii)

A major problem, though, arises: If the premises in iii) hold, the grammaticality of SVO sequences can be accounted for. However, it is now the ungrammaticality of VSO that cannot be justified, as it is difficult to explain why VS-orders cannot be assigned a legitimate interpretation at LF, namely one in which the [Spec, TP] copy is given semantic interpretation while the $v \mathrm{P}$-internal copy gets pronounced. In other words, since LF is free to interpret a different movement copy than the one pronounced by PF (and vice versa), the account of (10) given in iii) above cannot easily explain why VS orders are not given the grammatical representation in (13d):

(13) a. * $\operatorname{tin}_{\mathrm{i}}$ ayapai [i mitera [tis marias $]_{\mathrm{i}}$ ]

b. $\left[{ }_{\mathrm{TP}}\left[\mathrm{i}\right.\right.$ mitera $\left.[\text { tis marias }]_{\mathrm{i}}\right] \operatorname{tin}_{\mathrm{i}}$ ayapai $\left[{ }^{\mathrm{P}}\left[\mathrm{i}\right.\right.$ mitera $\left.[\text { tis marias }]_{\mathrm{i}}\right]$ ayapai $\left[\mathrm{vP}\right.$ ayapai $\left.\left.\left.\operatorname{tin}_{\mathrm{i}}\right]\right]\right]$ (output of narrow syntax)

c. $\left[{ }_{\mathrm{TP}}\left[\right.\right.$ i mitera $\left.[\text { tis marias }]_{\mathrm{i}}\right] \operatorname{tin}_{\mathrm{i}}$ ayapai $\left[{ }_{\nu \mathrm{P}}\left[\mathrm{i}\right.\right.$ mitera $\left.[\text { tis marias }]_{\mathrm{i}}\right]$ ayapai $\left[\mathrm{vP}\right.$ ayapai tin $\left.\left.\left._{i}\right]\right]\right]$ (PF-representation)

d. $\quad\left[\mathrm{TP}_{\mathrm{P}}\left[\mathrm{i}\right.\right.$ mitera $\left.[\text { tis marias }]_{\mathrm{i}}\right] \operatorname{tin}_{\mathrm{i}}$ ayapai $\left[{ }_{\nu \mathrm{P}}\left[\right.\right.$ i mitera $\left.[\text { tis marias }]_{\mathrm{i}}\right]$ ayapai $\left[\mathrm{vP}\right.$ ayapai tin $\left.\left.\left._{\mathrm{i}}\right]\right]\right]$ $(\text { LF-representation })^{10}$

Spyropoulos \& Revithiadou (2007) argue that the LF-interpretation of the lower copy in (13) derives from the following rule:

10) In this example (13d) strikethrough means LF-deletion and not phonetic deletion. 
(14) Minimize Mismatch (Bobaljik 2002: 251)

(To the extent possible) privilege the same copy at PF and LF.

However, the implementation of such a principle is problematic both on conceptual and on factual grounds.

First of all, arguing that the same copy should be pronounced and interpreted presupposes that the each interface can access information processed on the other. In other words, it assumes that the LF interface can 'see' which copy gets pronounced at the PF interface and privilege interpretation of this copy, and vice versa. However, this assumption is far from standard and it either undermines the architectural premise that the interfaces constitute domains which are absolutely distinct from each other, or requires the presence of a post-interface level/mechanism that can take care of such mismatches (a mechanism whose existence should be independently justified).

What is more, (14), if taken as a strict conformity requirement, might undermine the very essence of single-output approaches to syntax, for if it holds in all cases, then the interfaces will not be able to choose distinct copies for interpreting/spelling-out in any case.

But let us discuss the main factual problem of this account. The requirement that the pronounced copy should be the one that gets interpreted at LF applies 'to the extent possible', that is, only in case it leads to a convergent derivation. However, the interpretation of the lower copy does not lead to a convergent derivation in $(13 \mathrm{~d})$. It might, though, be suggested that since the only copy that leads to a legitimate semantic interpretation is the higher one, then PF should spell-out the [Spec, TP] copy, thus following Minimize Mismatch. Under this interpretation, spell-out of the lower copy should not even arise as an option.

However, we can construct an example where the [Spec, TP] copy cannot be pronounced but must be interpreted. According to Spyropoulos \& Revithiadou $(2007,2009)$ the $[$ Spec, TP] copy of the subject cannot be pronounced in cases where the subjunctive particle $n a$ occurs, since this is phonologically dependent and needs to cliticize on T. Given the fact that $n a$ occupies the head of a functional projection immediately above TP (Philippaki-Warburton 1998; Philippaki-Warburton \& Spyropoulos 1999; Roussou 2000), the presence of an overt subject in [Spec, TP] would disrupt the linear adjacency required for cliticization of $n a$ onto T. Spyropoulos \& Revithiadou (2007), on the other hand, side with Roussou \& Tsimpli (2006) in assuming that generic subject and subjects of stative verbs can be interpreted as such only if they occupy a T-related ([Spec, TP]) position. Thus, they observe that subjects of subjunctives in stative constructions are legitimate since the constructions in which they appear constitute instances of the interfaces privileging different copies: 
(15) a. ilpiza na kseri i maria tin apandisi

hope-past-1sg SUBJ know-non.past-3sg the maria-nom the answer-acc

'I hoped that Maria would know the answer.'

b. ilpiza na [те [imaria $\mathrm{i}$ kseri $[v \mathrm{P}[\mathrm{i}$ maria $]$ tin apandisi $]]$

copy interpreted at LF $\checkmark \quad$ copy spelled-out at PF $\checkmark$

So, according to Spyropoulos \& Revithiadou (2007) in cases where PF cannot pronounce the copy that gets interpreted at LF, it can go on to pronounce a lower copy (although LF interprets the high one). It is not clear why the same rationale that allows a relaxation of the Minimize Mismatch principle (or the activation of the 'to the extent possible' caveat) in (15) cannot extend to cases such as (16) where the higher copy cannot be pronounced due to na-cliticization, while the lower one gives rise to a Principle $\mathrm{C}$ violation.

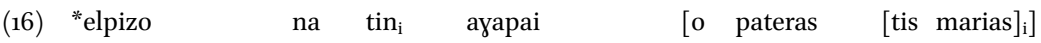
hope-non.past-1sg SUBJ her-acc love-non.past-3sg the father-nom the Mary-acc

'I hope that Mary's father loves her.'

We would expect that (16) could be grammatical under a situation such as (17) in tandem with (15), contrary to facts:

(17) elpizo na [тР [Opateras [tis marias $\left.]_{i}\right] \operatorname{tin}_{\mathrm{i}}$ ayapai [o pateras [tis marias $\left.]_{\mathrm{i}}\right]$

copy interpreted at LF $\checkmark \quad$ copy spelled-out at PF $\checkmark$

We conclude that the ungrammaticality of VS order such as (16) in Principle C violation configurations cannot be accounted for by any account that relates the surface and the base position of a preverbal subject with a movement operation. Thus, the only way to explain the asymmetry in (10) would be to assume that the preverbal subject in (1ob) occupies a base-generated left-peripheral preverbal position, as proposed by Panagiotidis \& Tsiplakou (2006).

However, this conclusion, which I take to be valid, does not constitute a knock-out argument against subject movement to [Spec, TP] in Greek, as it could be argued that $\mathrm{EPP}_{\mathrm{T}}$-induced movement does take place in Greek, but (10b) instantiates a different scenario, namely a base-generated structure. As we saw in subsection 3.1 the existence of base-generated preverbal subjects in the left periphery is virtually uncontested. So, it could be the case that structures such as (10b) are base-generated orders, in which the thematic position is occupied by an argumental pro, which checks the $\mathrm{EPP}_{\mathrm{T}}$-feature by regular movement to [Spec, TP]:

(18) $\quad\left[\text { i mitera }[\text { tis marias }]_{\mathrm{j}}\right]_{\mathrm{i}}\left[\mathrm{TP}[\mathrm{DP} \text { pro }]_{\mathrm{i}} \operatorname{tin}_{\mathrm{j}}\right.$ ayapai $\left[{ }_{\mathrm{pP}}[\mathrm{DP} \text { pro }]_{\mathrm{i}}\right.$ ayapai $\left[\mathrm{vP}\right.$ ayapai tin $\left.\left.\left._{\mathrm{j}}\right]\right]\right]$ 
Note that in the configuration above the preverbal subject is merely coindexed with the argumental pro and, hence, its complement tis marias is never in the scope of the clitic. As a consequence, no Principle $C$ violation arises. The above configuration is, therefore, homophonous with the ungrammatical (19), which is out for the reasons that we have been discussing so far:

(19) * ${ }^{*}\left[\mathrm{TP}\left[\mathrm{i} \text { mitera }[\text { tis marias }]_{\mathrm{j}}\right]_{\mathrm{i}}\right.$ tin $_{\mathrm{j}}$ ayapai $[\nu \mathrm{p} \text { [i mitera [tis marias }]_{\mathrm{j}} \mathrm{f}_{\mathrm{i}}$ ayapai [vp ayapai tin $\left.\left.\left._{\mathrm{j}}\right]\right]\right]$

This account, however, cannot provide a way out to 'A-movement-to-[Spec, TP]' approaches. First of all, such dual explanation for SVO structures (i.e. the fact that we might have the same surface order as both a base-generated left dislocation structure and as a regular subject A-movement configuration) requires the reintroduction of the coindexation mechanism (which single-output approaches seek to eliminate), whereby a dislocated element gets identified as a verbal argument via coindexation with the 'real' argument, a phonetically null pronominal. Secondly, the claim that (10b) is a case whereby the preverbal subject is not occupying the [Spec, TP] position (a claim which I totally agree with) gives rise to interesting conclusion with respect to the semantic interpretations related to T by Roussou \& Tsimpli (2006) and/or Spyropoulos \& Revithiadou $(2007,2009)$. More specifically, such an account cannot explain why legitimate preverbal subjects in potential Principle $C$ violation constructions exhibit characteristics that those works tie to T-related A-positions.

Thus, preverbal subjects in clitic structures (with the aforementioned coindexed reading possible) permit sub-extraction of a wh-possessor, a property that Spyropoulos \& Revithiadou (2009) attribute to [Spec, TP] elements:

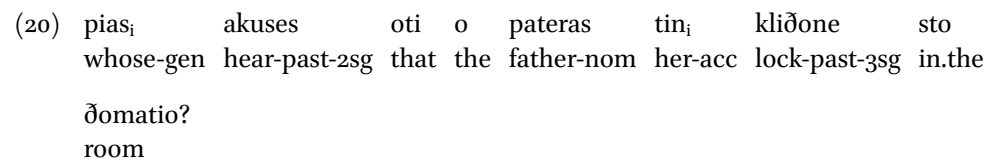

(coreferential reading possible)

If the preverbal subject in (20) is in a base-generated dislocated position (and we have argued extensively that this is the only possibility that makes sense), then the possibility of possessor sub-extraction from a preverbal subject cannot be a diagnostic for its being in a T-related position. Thus, one of Spyropoulos \& Revithiadou's (2009) arguments for the A-nature of the [Spec, TP] position, namely the possibility of sub-extraction from preverbal subjects, cannot be said to be (exclusively) related to [Spec, TP].1

11) Note here that Spyropoulos \& Revithiadou's (2009) argument runs counter to the much of 
What is more, in SVO structures in Principle C violation constructions we can find generic subjects, which, according to Roussou \& Tsimpli (2006) may surface only in $d_{\mathrm{T}}$ and, according to Spyropoulos \& Revithiadou (2009) can only occupy [Spec, TP] (since they cannot be interpreted as topicalized elements). Consider (21):

(21) i apofiti [tis sxolis kalon texnon $]_{i} \operatorname{tin}_{\mathrm{i}} \theta$ imunde pandote the alumni the school-gen good arts-gen it-acc remember-non.past-3pl always

'The alumni of the School of Arts always remember it.'

As an interim conclusion, we saw that any approach according to which preverbal subjects are derived through movement to a pre-clitic $\mathrm{EPP}_{\mathrm{T}}$-position cannot explain the contrast in (10). The only possible way of explaining the curious pattern of Principle C effects observed in (10) would be to assume that the SV and VS orders involved have distinct derivations, corresponding to distinct lexical arrays/numerations, with VS involving $v$ P-internal in situ subjects and SV involving base-generated left-peripheral DPs coindexed with argumental pros, as proposed in Panagiotidis \& Tsiplakou (2006). However, in the latter case (which we take to be valid), it is shown that those preverbal base-generated DPs can manifest semantic or configurational properties, which may not, then, be associated exclusively with [Spec, TP].

\subsubsection{Cliticization of Preverbal Particles}

A further argument for the unavailability of [Spec, TP] for either overt or covert material can be derived from the positioning of preverbal particles. These are the modal particles $n a$ and $a$ s, the negation particles ðen and min, and the particle $\theta a$ expressing either mood (Roussou 200o) or future (Philippaki-Warburton 1998). These particles have been assumed to head their own projections above TP in work by Rivero (1994), Rivero and Terzi (1995), Philippaki-Warburton (1998), Philippaki-Warburton \& Spyropoulos (1999), and Roussou (2000).

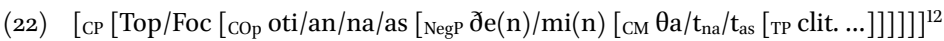

(Roussou 2000)

\footnotetext{
the literature on $w h$-sub-extraction from subjects, which takes the [Spec, TP] position to be the offending one (cf. work by Takahashi 1994; Stepanov 2001; Richards 2001, 2006; Boeckx 2003, 2008; and Kotzoglou 2005, 2010 for Greek).

12) Where 'CM' is the modal complementizer and 'COp' is an operator position in Roussou's (200o) system.
} 
The fact that those preverbal particles head their own functional projections and constitute distinct functional projections not related to the [T-V] complex via regular head movement has been well documented in the literature. In fact, the ungrammaticality of negative imperatives in Greek has been attributed to the fact that the negative particle (located on $\mathrm{Neg}^{0}$ ) intervenes between $\mathrm{T}$ (whereby $\mathrm{V}$ has raised) and the head containing the mood affix ( $\mathrm{C}$ or Mood). Hence, the ungrammaticality of structures like (23) has been attributed to either a violation of the Head Movement Constraint (Rivero 1994; Rivero \& Terzi 1995; Philippaki-Warburton 1998; Kotzoglou 2006) or a violation of the requirement for linear adjacency required for affixation (Bošković 2004). In any case, the fact that the preverbal particles cannot be cliticized onto the verb and cannot get carried along to higher inflectional heads (such as the one that contains the exponent of imperative mood), constitute a solid argument that preverbal particles are not T-related elements.

(23) *mi yrapse!

NEG write-imper-2sg

'Don't write!'

Based on evidence such as the above, Philippaki-Warburton \& Spyropoulos (1999) argue that preverbal particles retain their head positions in narrow syntax, without inducing head movement, and cliticize onto T postsyntactically, as they are phonologically reduced elements. This approach presupposes, then that nothing disrupts the linear adjacency between these particles and their host, the Thead.

Given that particles occupy the functional heads right above the TP projection, we would expect that they ban the presence of overt material in [Spec, TP]. Indeed, Spyropoulos \& Revithiadou (2009), as we discussed in the previous subsection, attribute the V-S order evidenced in subordinate subjunctive clauses to the fact that such structure prohibit spell-out of the [Spec, TP]-copy of the subject, due to the fact that this copy intervenes between the subjunctive particle $n a$ and the main verb (cf. example (1)).

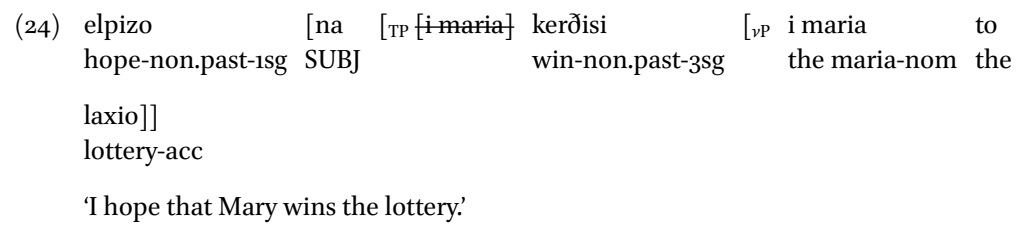

We agree with Spyropoulos \& Revithiadou (2009) that no material can intervene between $n a$ and the verb (on T) and, hence, that preverbal subjects of subjunctive verbs may not be situated in [Spec, TP]. However, not only na but 
also all preverbal particles are clitic in nature, i.e. they need to attach phonologically to $\mathrm{T}$ in the same way that $\mathrm{na}$ does (cf. discussion in Philippaki-Warburton \& Spyropoulos 1999). We are, therefore, led to the conclusion that preverbal subjects in constructions involving verbs preceded by particles are necessarily in a left-dislocated position:

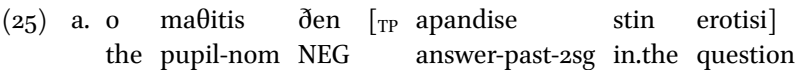

'The pupil did not answer the question.'

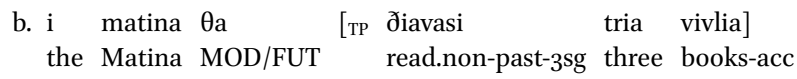

'Matina will read three books.'

Notice, now, that in the Subject-particle(s)-[T $\mathrm{V}-\mathrm{T}]$ order subjects are allowed to exhibit the full list of properties that according to Roussou \& Tsimpli (2006) and Spyropoulos \& Revithiadou (2009) are characteristics of T-related preverbal subjects. Namely, such subjects allow possessor sub-extraction (26a), and can support generic readings $(26 \mathrm{~b}-\mathrm{c})$ or be subjects of stative verbs $(26 \mathrm{~d})$ :

(26) a. tinos ipes oti o pateras su tilefonise?

whose say-past-2sg that the father-nom you call-past-3sg

'Whose father did you say called you?'

b. i falenes $\theta$ a eksafanistun arya i jriyora the whales MOD disappear-non.past-3pl late or soon

'Sooner or later, whales will disappear.'

c. i fitites ðen piyenun se ekðromes

the students-nom NEG go-non.past-3pl to excursions

'The students do not go to excursions.'

d. i fititria ðen kseri tin apandisi

the student-nom NEG know-non.past-3sg the answer-acc

'The student does not know the answer.'

Since the requirement for linear adjacency between the preverbal particles and the verb (on T) is well-established, and given that (according to Roussou 2000) the particles are heads of projections that mark the C-domain, ${ }^{13}$ the conclusion we draw is that the host of interpretations that Roussou \& Tsimpli

13) Philippaki-Warburton (1998) argues that the hierarchy of projections which host preverbal particles constitutes an extended I-domain, while Roussou (2000) considers those projections to be parts of an extended C domain (cf. Rizzi 1997). However, even in Philippaki-Warburton's analysis elements appearing before the particle heads cannot be said to occupy [Spec, TP]. 
(2006) attribute to $d_{\mathrm{T}}$-subject can also be given to subjects that appear in the $d_{\mathrm{C}}$-domain and, therefore, such readings do not constitute clear evidence for the presence of preverbal verbs in $[\mathrm{Spec}, \mathrm{TP}] / d_{\mathrm{T}}$.

\subsubsection{Non-Topicalized Preverbal Subjects Need Not Appear in $[\mathrm{Spec}, \mathrm{TP}] / \mathrm{d}_{\mathrm{T}}$}

The previous subsections contained the first hints towards the conclusion that the obligatory non-topicalized readings of some preverbal subjects, observed by Roussou \& Tsimpli (2006), cannot be tied to a specific configurational position (more specifically [Spec, TP] or a position in $d_{\mathrm{T}}$ ). We further observe that elements that uncontroversially belong to the left periphery of the clause (such as contrastively focused phrases (27) or clitic-left dislocated phrases (28)) may intervene between those kinds of subject and the verb (or T).

(27) a. i falenes OILASTIKA ine (oxi psaria)

the whales-nom MAMMALS are not fish

'Whales are MAMMALS (not fish).'

b. i fitites se ĐIAĐILOSIS piyenun (oxi se ekðromes)

the students-nom to demonstrations go-non.past-3pl not to excursions

'Students go to DEMONSTRATIONS (not to excursions).'

c. ta lina EFKOLA plenonde (oxi ðiskola)

the linens-nom easily wash-non.past-pass.3pl not with.difficulty

'It is EASILY that linens wash, not with difficulty.'

(28) i fititria tin apandisi tin kseri kala

the student-nom the answer-acc it know-non.past-3sg well

'The student knows the answer well.'

Given the fact that in Roussou's (2000) system (22) the position that host topics and foci are situated in the C-domain, the preverbal subjects in (27-28) must also be situated in a non T-related position, despite their generic or stative meaning.

\subsubsection{On the (Non)-Existence of Other Preverbal A-Positions}

In the preceding subsections we argued against the claim that Greek preverbal subjects occupy the [Spec, TP] position. We also claimed that the interpretations that Roussou \& Tsimpli (2006) attribute to non-topicalized elements cannot be identified with [Spec, TP]. However, our discussion so far does not preclude the possibility that the canonical $\mathrm{EPP}_{\mathrm{T}}$-position in Greek is in fact projected higher than [Spec, TP]. 
In subsection 3.1, we argued that the theoretical formulation of such a proposal would be far from trivial. The empirical justification, though, seems to run into problems as well.

First, as already discussed, the binding asymmetry noted in (10) cannot be explained if we assume subject movement to any A-specifier above the binding position of the clitic in SV structures, no matter whether this [Spec, TP] or some other A-specifier.

Second, it has been shown that all preverbal subjects in Greek act as blockers of cyclic $w h$-movement. Thus, movement of a $w h$-phrase across a preverbal subject gives slight ungrammaticality results, while no such effects are evidenced if the subject is postverbal (Anagnostopoulou 1994; Alexiadou 1996; Kotzoglou 2006 — see Zubizarreta 2001 for a similar observation in Romance):

(29) a. ?pion ipes oti o yioryos kalese?

who -acc say-past-2sg that the George-nom invite-past-3sg

'Who did you say George invited?'

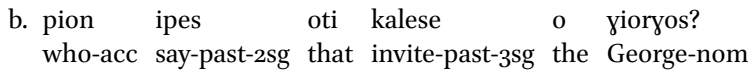

'Who did you say George invited?'

It can be easily understood that the strong preference for VS embedded orders in $w h$-movement contexts is not due to T-to-C movement since the overt complementizer (oti) occupies the $\mathrm{C}^{0}$ head in both sentences above and it should act as a blocker of such a movement (see Kotzoglou 2006 for the claim that Greek does not exhibit T-to-C head movement). Moreover, the preverbal particles of negation, which block verb movement, may appear in extraction contexts:

(30) a. ?pion ipes oti o yioryos ðen kalese? who-acc say-past-2sg that the George-nom NEG invite-past-3sg

'Who did you say George didn't invite?'

b. pion ipes oti ðen kalese o yioryos?

who-acc say-past-2sg that NEG invite-past-3sg the George-nom

'Who did you say George didn't invite?'

The degradation of $w h$-extraction from embedded SV sentences has been attributed to the fact that preverbal subjects occupy operator positions, thus acting as minimality blockers for similar kinds of movement (i.e. wh-movement in our case), in the sense of Rizzi $(1990,2001){ }^{14}$

14) An anonymous reviewer points out that if examples such as (29a) are due to a minimality 
What is interesting is the fact that even embedded preverbal generic subjects and subjects of statives seem to block $w h$-extraction, while corresponding postverbal ones do not:

(31) a. ?ti zoa ipes oti i falenes ine?

what animals say-past-2sg that the whales are

'What kind of animals did you say are whales?'

b. ti zoa ipes oti ine i falenes?

what animals say-past-2sg that are the whales

'What kind of animals did you say are whales?'

c. ?pos ipes oti ta lina plenonde?

how say-past-2sg that the linens wash-pass-3sg

'How did you say that linens wash?'

d. pos ipes oti plenonde ta lina?

how say-past-2sg that wash-pass-3sg the linens

'How did you say that linens wash?'

(32) a. ?ti ipes oti i fititria kseri?

what-acc say-past-2sg that the student know-non.past-2sg

'What did you say the student knows?'

b. ti ipes oti kseri i fititria?

what-acc say-past-2sg that know-non.past-2sg the student

'What did you say the student knows?'

\subsubsection{On Control in Manner Gerunds}

Let us now turn to a potential argument in favour of a derived preverbal position. Spyropoulos \& Revithiadou (2007), following similar observations of Spyropoulos (1999) and Spyropoulos \& Philippaki-Warburton (2001) argue that the

violation we should expect stronger degradation in instances of adjunct extraction. However, no such contrast is observe. Note, though, that extraction of $w h$-adjuncts from embedded clauses with a topicalized element in Greek tend to give ?-readings on a par with extraction from wharguments:

(i) ?pote ipes oti to mixanaki to ayorase o yianis?

when say-past-2sg that the motorcycle cl buy-past-3 the John

'When did you say John bought the motorcycle.'

(embedded reading of when)

(ii) ?ti ipes oti tis marias tis xarise o yianis?

what say-past-2sg that the Mary-gen cl give-present-past-3sg the John

'What did you say John gave Mary as a present?' 
presence of a derived copy of the subject in [Spec, TP] might explain the fact that the null PRO subject of Greek manner gerunds (which head constituents that occupy a $v$ P-adjoined position) is obligatorily controlled by the subject of a clause and never by the complement of a transitive verb.

(33) $[\mathrm{i} \text { maria }]_{\mathrm{i}}$ kitakse [ton $\theta$ ano $]_{\mathrm{j}}\left[\mathrm{PRO}_{\mathrm{i} /{ }^{*} \mathrm{j}}\right.$ yelondas $]$ the Mary look-at-past-3sg the Thanos PRO laughing

'Mary, laughing, looked at Thanos.'

On the other hand, the fact that even complements of unaccusative verbs (i.e. underlying objects) may act as controllers (34) is taken to be an indication that control is exerted not from the $v \mathrm{P}$-internal position(s) but from a derived position (such as [Spec, TP]).

(34) i porta anikse trizondas

the door-nom open-mid.-3sg squeaking

'The door opened with a squeak.'

(Spyropoulos 1999)

Subjects of both transitives and unaccusative predicates may act as controllers of the subject of a manner gerund even from the postverbal position

(35) kitakse $\quad[\mathrm{i} \text { maria }]_{\mathrm{i}} \quad\left[\begin{array}{llll}\text { ton } \theta \mathrm{ano} & ]_{\mathrm{j}} & \text { PRO laughing }\end{array}\right.$

look-past-3sg the Mary-nom the Thanos-acc $\left[\mathrm{PRO}_{\mathrm{i} /{ }^{* *} \mathrm{j}}\right.$ jelondas]

'Mary looked at Thanos'

(36) $\operatorname{ir} \theta \mathrm{e} \quad\left[\begin{array}{ll}\mathrm{o} & \theta \mathrm{anos}\end{array}\right]_{\mathrm{j}} \quad\left[\mathrm{PRO}_{\mathrm{j}}\right.$ yelondas $]$

arrive-past-3sg the Thanos-nom PRO laughing

'Thanos arrived laughing.'

However, this argument in favour of the existence of material in [Spec, TP] cannot go through. Consider (37), where the PRO-subject of the gerund is controlled by the external argument of the embedded verb.

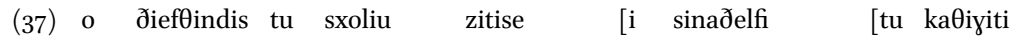
the head-nom the school-gen ask-past-2sg the colleagues-nom the professor-gen

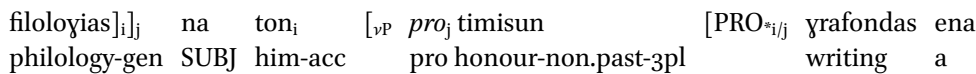
ðiiyima sti sxoliki efimeriða]] short.story in.the school newspaper

'The head of school asked the colleagues of the professor of philology to honour him by writing a short story in the school's newspaper'

For the reasons discussed in subsection 3.2.1, we assume that the preverbal subject $i$ sinaðelfi tu kaviyiti filoloyias is a left-dislocated element, since its complement can be freely coindexed with the clitic ton without a Principle $\mathrm{C}$ violation. 
However, at this point two crucial questions arise: First, how can an A'-element, such as the left dislocated subject, act as a controller (given the prohibition of object control from a non-A position)? Second, why can't the PRO subject of the gerundival clause be controlled by the clitic ton? Note that ton occupies an A-position (otherwise it could not be able to act as a binder in (10a)) and is closer to PRO than the preverbal subject. However, curiously enough, control by the clitic is excluded as an interpretation for (37). The latter question would

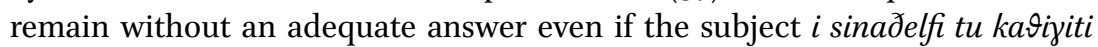
filoloyias did occupy the [Spec, TP] position. Therefore, the explanation according to which the controller of PRO in (37) is the full preverbal subject cannot be maintained.

We are forced, then, to seek for another explanation to both the control properties of (37) and the pattern in $(33-34)$, one that would exclude the possibility that a $v$ P-external element would control the PRO subject of the gerund, while retaining the derived subject-surface object asymmetry in potential controllers. On the face of data such as (37) we may assume, then, that the controller of PRO is the in-situ pro subject of $v$ P. By virtue of being on the edge of the $v \mathrm{P}$, the subject may take scope over everything that is contained in the $v \mathrm{P}$, including adjoined gerundial clauses. By being directly merged in $[\mathrm{Spec}, \nu \mathrm{P}]$ the subject qualifies as a closer controller to PRO than the clitic which raises to the periphery of $\nu \mathrm{P}$ in the course of derivation ${ }^{15}$ (see Rosenbaum 1970; Hornstein 2001 on minimality effects in the choice of the controller).

However, control by the in-situ complement of ergative predicates, such as (34), seems to be unaccounted for. Let us consider, though, that ergative verbs project not a fully-fledged $\nu \mathrm{P}$ but a mere VP comprising the verb and its sole argument:

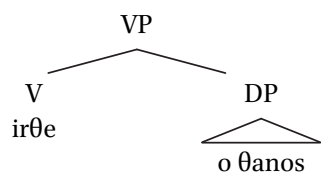

Since Chomsky's (1994) Bare Phrase Structure model, it has been recognized that the notions 'specifier' and 'complement' are derivative and that they are used only for convenience. Therefore, the sole argument of an ergative verb can be taken to be on the 'edge' of VP in pretty much the same way that the external argument of a transitive verb is merged on the 'edge' of $v \mathrm{P}$ (recall that linearization is imposed by PF and, therefore, is irrelevant for hierarchical considerations). With the above premises at hand, we can provide a uniform

15) The fact that the intermediate position of the moved clitic has to be higher than that of the in-situ subject is confirmed by the binding properties of (10a). 
explanation to the choice of controller for the PRO-subject of manner gerunds: Gerundial clauses are adjoined to the highest $\nu \mathrm{P} / \mathrm{VP}$ shell and their subject is obligatorily controlled by the closest argument of the $\nu \mathrm{P} / \mathrm{VP}$ (with distance evaluated in terms of c-command).

\subsubsection{On $\mathrm{EPP}_{\mathrm{T}}$-Checking by a Null Subject Clitic}

Let us, now, turn to the discussion of Spyropoulos's (1999) and Spyropoulos \& Philippaki-Warburton's (2001) claim that the subject in Greek consists of a discontinuous chain. These approaches seek to retain the $\mathrm{EPP}_{\mathrm{T}}$-position and argue that the $\mathrm{EPP}_{\mathrm{T}}$-feature is checked by a phonetically null subject clitic, similar to those encountered in Italian dialects (Brandi \& Cordin 1989). The null subject clitic is further coindexed with an associate pro or full DP (in VS-orders) in the $\nu$ P-internal thematic position and (possibly) with a preverbal left-dislocated full DP (in SV-orders):

（39） $\quad\left(\mathrm{DP}_{\mathrm{i}}\right)\left[{ }_{\mathrm{TP}}\langle\text { subj.clitic }\rangle_{\mathrm{i}} \ldots\left[{ }_{\text { }}{ }_{\text {P }}\right.\right.$ pro $_{\mathrm{i}} /$ DPsubject $\left.\left._{\mathrm{i}}\right]\right]$

On the view of such an analysis, though, VS-orders in Greek, as (virtually) transitive expletive constructions, should exhibit the definiteness restriction (cf. Safir 1982, 1987; and the similar conclusion in Alexiadou \& Anagnostopoulou 1998). Namely, the $\nu \mathrm{P}$-internal associate of the [D]-element on [Spec, TP] should be indefinite. However, no definiteness restriction arises in Greek inverted orders:

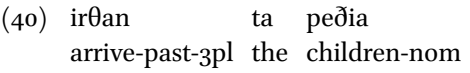

'The children arrived'

Moreover, as the subject clitic and the full $\nu$ P-internal DP are different elements of the numeration/lexical array the computational mechanism considers them to be distinct entities and we would expect movement of the lexical DP across the subject clitic to give rise to Strong Crossover effects, as happens in the case of clitic left dislocated objects:

(41) ${ }^{*}$ pion $_{\mathrm{i}} \quad$ ton $_{\mathrm{i}}$ iðes?

who-acc him see-past-2sg

'Who did you see?'

(42) $\operatorname{pios}_{\mathrm{i}} \quad\left[\mathrm{TP}\langle\text { subj.clitic }\rangle_{\mathrm{i}}\right.$ eyrapse $\left[{ }_{\nu \mathrm{P}} \mathrm{t}_{\mathrm{i}}\right.$ ton amlet $\left.]\right]$ ?

who-nom subject.clitic write-past-3sg the Hamlet-acc

'Who wrote 'Hamlet'?'

In Spyropoulos \& Philippaki-Warburton's (2001) system the choice of the silent subject clitic as the element occupying [Spec, $\mathrm{TP}]$ is default and, hence, an overt 
DP cannot pass through this position (say, on its way to a higher Spec). Thus, the asymmetry presented in (41-42) remains unaccounted for.

Finally, as extensively discussed in Philippaki-Warburton $(1975,1985)$, Tsimpli $(1990,1995)$, clitics in Greek act as topicalization markers with the effect of backgrounding their associates, which cannot receive new information interpretation. No such effect is observed in inverted subjects in Greek. Such subjects may bear both information and contrastive focus, as extensively discussed in virtually all works on Greek focus constructions (for an overview see Georgiafentis 2004):

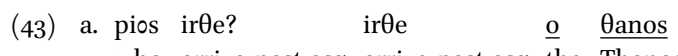

who arrive-past-3sg arrive-past-3sg the Thanos

'Who arrived? Thanos arrived.'

b. irӨe o $\quad$ AANOS (oxi o aleksis)

arrive-past-3sg the Thanos not the Alexis

'THANOS arrived, not Alexis.'

On the face of the evidence above, we conclude that the Discontinuous Subject Hypothesis cannot be maintained as such.

Summarizing section 3 , we saw that numerous pieces of evidence militate against the view that preverbal subjects in Greek are moved to a T-related ([Spec, TP]) preverbal position from their thematic one in the sense of, say English, A-movement. Preverbal subjects in Greek seem to be base-generated elements associated with base-generated null pros. ${ }^{16}$

\section{On the Position of Greek Postverbal Subjects}

In this section we argue that subjects in Greek VS orders may stay in their base position. We know of no work that refutes that this is a possibility, but as the syntactic simplicity of VSO is a prerequisite for its being identified as the 'basic'/most unmarked word order, we need to review the relevant arguments.

A configurational argument in favour of the proposal that inverted subjects in VSO need not evacuate $v$ P has been offered in Alexiadou (1999), who observes that inverted subjects may appear on the right of light manner adverbs, which are assumed to mark the left edge of $v \mathrm{P}$ :

16) It is fair to note here that Spyropoulos \& Revithiadou (2009) convincingly show that preverbal subjects in Greek prosodify in a manner akin to other arguments and unlike adjoined material. To the extent that such evidence from the interface constitutes ground for the claim of the subject's occupying a specific configurational position, their result cannot be readily accommodated in the proposal advanced in this paper. I have no insightful way to account for the prosodification patterns at the moment. 
(44) an exun iði maقi kala i kokini to sistima tus if have-non.past-3pl already learn well the reds-nom the system-acc their-gen

A second argument is theory-internal. Let us suppose that postverbal subjects did move to the specifier of a projection (let us call it XP) situated below T. Let us further assume that this kind of movement had to take place in all cases (for, if the subject could remain in the $v \mathrm{P}$-internal position in at least some cases, we would conclude that postverbal subject might remain in-situ, QED). In case this projection $\mathrm{X}$ were an A-projection, related to $\varphi$-feature checking, then movement of the subject to [Spec, XP] would be motivated by and result in checking of the $\varphi$-features and the EPP-feature of the X head as well as in the ancillary valuation of the case feature of the moved subject. However, such an operation would render the subject DP frozen in place and invisible to further operations (Chomsky 2000, 2001). As a consequence, T would not be able to identify the subject DP and enter a matching and Agree relation with it. However, $\mathrm{T}$ does enter an Agree relation with the inverted subject, as its $\varphi$-features take the values of the subject-DP. What is more, the postverbal subject ends up with nominative case, which, we assume, is assigned by $\varphi$-complete T. We conclude that postverbal subjects in Greek may not move to an A-position. On the other hand, if X were not a $\varphi$-feature related head (i.e. if [Spec, XP] were an $\mathrm{A}^{\prime}$ position), then the postverbal subject should function as an $\mathrm{A}^{\prime}$-position and we would expect it to block $\mathrm{A}^{\prime}$-dependencies such as wh-movement of other constituents across it. However, as we saw in $(29 \mathrm{~b})$ and $(30 \mathrm{~b})$ no such effect arises. We conclude that subjects in Greek wide-focus $\mathrm{VS}(\mathrm{O})^{17}$ occupy their first-merge position.

In view of the above, I take sides with numerous studies that claim widefocus VS(O) orders involve an in-situ subject in the $\nu \mathrm{P}$-internal position (such as, to name but a few, Alexiadou 1999: 52; Sifaki 2004: 200; Georgiafentis 2004: 295).

\section{Implications for the $\mathrm{EPP}_{\mathrm{T}}$}

The conclusions reached in the previous sections, namely the well-formedness of VSO involving unmoved subjects and the unavailability of the 'canonical'EPP position [Spec, TP] or any other default preverbal A-position to subjects in

\footnotetext{
17) Nothing in our analysis precludes the possibility of alternative derivations of word orders, which might involve further movement operations with the effect of the creation of different readings as a result of the difference in information packaging associated with specific configurations (cf. the proposals in Philippaki-Warburton 2001; Georgiafentis 2004).
} 
Greek lead to the question of the exact nature of the $\mathrm{EPP}_{\mathrm{T}}$-feature and to the way this feature is checked in Greek (and, presumably, other null subject languages). For, if VS orders are grammatical without either overt or covert raising of the subject to [Spec, TP] then the universality of the EPP in its initial formulation (Chomsky 1981), as a requirement that [Spec, TP] gets filled with the subject of the sentence, cannot be maintained.

However, dispensing with one conception of the $\mathrm{EPP}_{\mathrm{T}}$ does not mean refuting its existence altogether, as the Extended Projection Principle has recently come to assume numerous guises and it is given a number of different meanings in syntactic theorizing (cf. discussion in Landau 2007). Thus it might be that the $\mathrm{EPP}_{\mathrm{T}}$ is not about the presence of a phrase bearing a [D] feature on [Spec, TP] (Chomsky's 1995 extension of the intuition behind the initial EPP), but it reduces a requirement for overt realization of [Spec, TP] (Sifaki 2003, 2004). In other words, it might be the case that $\mathrm{EPP}_{\mathrm{T}}$ consists of a $[\mathrm{P}]$ (honological)feature, requiring merge of any overt phrase in [Spec, TP] (cf. similar proposals by Holmberg 2000; Holmberg \& Hróarsdóttir 2003; Landau 2007). However, this approach is not unproblematic either.

First, if indeed the $\mathrm{EPP}_{\mathrm{T}}$-feature (or [P]-feature) can be checked by material other than the subject of the sentence, such as whole VP constituents (in Sifaki's 2003, 2004 system), then the question of the simplicity or unmarkedness of the different word order permutations in Greek does not even arise. Since VP-fronting is said to derive all constituent orders, both marked and unmarked ones, the differences in the information load (and, consequently, in the frequency of occurrence) of the different word order permutations cannot be solely attributed to syntactic factors (apart from the Nuclear Stress Rule), an undesired result. In other words, the proposed account cannot explain why VSO with focus on S is far more preferred structure than VOS with focus on S in Greek, as both orders in Sifaki's system are produced through the same mechanism, namely VP preposing to [Spec, TP]. ${ }^{18}$

Second, Sifaki's $(2003,2004)$ analysis ignores the fact that Greek exhibits overt V-to-T movement, as all V-initial word orders in her system are produced through fronting to [Spec, TP/IP] of the lower VP-shell which contains the main verb (although the author argues that V-to-v movement exists). Application of narrow syntactic $\mathrm{V}$-movement to $\mathrm{T}$, an operation whose existence has not been put in question in the literature on Greek, would destroy the configuration required for the system to work.

18) The factor that gives rise to two different derivations (VSO vs VOS), namely the fact that the $\mathrm{O}$ has evacuated the fronted VP in VOS and the fact that both the $S$ and the $O$ have evacuated the VP in VSO cannot account for the difference in the statistical frequency of appearance of two word orders. 
Furthermore, as Sifaki (2003) observes, the phonological account cannot explain how the $\mathrm{EPP}_{\mathrm{T}}$-requirement is satisfied in impersonal sentences, or sentences involving weather predicates, where the verb is the only overt element in the sentence.

What is more, the very motivation for the postulation of VP-fronting to [Spec, $\mathrm{TP}$ ] in Greek (a novel proposal in the literature on Greek) relies heavily on the postulation of the existence of a [P]-feature on T/I in Sifaki $(2003,2004)$. In turn, the postulation of the existence of this feature comes as a result of the conclusion that the $\mathrm{EPP}_{\mathrm{T}}$ cannot be a mere requirement for the presence of a [D]-element in [Spec, TP] plus the need for the construction of certain configurations to allow Nuclear Stress Rule produce the desired focus results. However, in lack of independent motivation, such a bold proposal might be masking a crucial conceptual flaw: the whole system works under the premise that the $\mathrm{EPP}_{\mathrm{T}}$ is universal. It is far from clear, though, that the existence of $\mathrm{EPP}_{\mathrm{T}}$ should be taken from granted. Once this premise is removed and the existence of the $\mathrm{EPP}_{\mathrm{T}}$-feature (and, therefore, the $[\mathrm{P}]$-feature) is put into question, the logic becomes circular: VP-preposing is invoked in order to make the $[\mathrm{P}]$-feature account work, while the existence of the [P]-feature gets justified through its effects on VP-preposing.

A final argument in favour of the postulation of an $\mathrm{EPP}_{\mathrm{T}}$-feature remains. Alexiadou \& Anagnostopoulou (1998) claim that the $\mathrm{EPP}_{\mathrm{T}}$-feature (EPP on AgrS in their account) is universal, but the way this feature gets checked is a matter of parametric variation across languages. Non-pro-drop languages check it through phrasal movement of a category bearing the [D]-feature to [Spec, TP].$^{19}$ Pro-drop languages check it through movement of $\mathrm{V}$ (bearing a [D] pronominal categorial feature) to the $\mathrm{T}$ head.

A first observation to such an account, at least as far as Greek is concerned, is that it is formulated in a way that makes it almost unfalsifiable. Greek does exhibit pro-drop uniformly and so all sentences may appear without an overt subject and, if our discussion in subsection 3.2 is correct, all sentences (even those exhibiting S-initial orders) contain an empty [Spec, TP]. Secondly, Greek has overt V-to-T movement in all clauses, presumably due to the richness in verb morphology. What cannot be shown through language-particular independent evidence is that these two properties are necessarily related to the extent that the latter has the former as its effect.

19) Actually, [Spec, AgrSP] in Alexiadou \& Anagnostopoulou's (1998) study, but I will continue calling [Spec, TP] here for the sake of uniformity of exposition. 
Furthermore, as observed by Spyropoulos (1999) and Spyropoulos \& Philippaki-Warburton (2001) the argument according to which EPP is checked by a $[D]$ categorial feature faces a potential problem in the case of impersonal constructions in Greek, such as $(45,46){ }^{20}$

(45) vrexi

rain-non.past-3sg

'it rains'

(46) fenete [oti i matina ayorase] ena vivlio seem-non.past-3sg that the Matina buy-past-3sg a book-acc

'It seems that Matina bought a book.'

In such constructions, the verbs surface with default impersonal agreement, yet the $\mathrm{EPP}_{\mathrm{T}}$-position remains empty (no overt expletive is required). The problem for the V-to-T checking analysis of null [Spec, TP] amounts to the fact that default verbal morphology is non-referential and, therefore-interpretable. It is questionable whether default agreement can carry a clitic-like personal [D] feature, such as the one required for $\mathrm{EPP}_{\mathrm{T}}$-checking via head movement. ${ }^{21} \mathrm{In}$ any case, we can conclude, though, that for the purposes of our discussion, i.e. the significance of the subject position for the question of the basic word order in Greek, Alexiadou \& Anagnostopoulou's (1998) account makes the same predictions as the one we shall propose below, namely that the $\mathrm{EPP}_{\mathrm{T}}$-requirement is suspended in Greek.

Summarizing, all possible formulations of the $\mathrm{EPP}_{\mathrm{T}}$-requirement as a universal seem to run into problems when it comes to Greek (not surprisingly, similar concerns have been raised for other null subject languages, as well). a) Its conception as a [D] feature on $\mathrm{T}$, triggering displacement of the subject to [Spec,

20) The argument has been repeated and used in Kotzoglou (2001), Sifaki (2003, 2004), Sifaki \& Sitaridou (2007).

21) An anonymous reviewer points out that expletive it in English weather constructions is also non-referential, yet it checks the EPP-feature of T. However, the major difference between the two languages is that overt expletives in English are dissociated from the main verb, they are independent elements in the numeration. On the other hand, verbal agreement morphology in Greek is manifested on $\mathrm{V}$, and the question that arises is why should one assume that a nonreferential (and nonargumental) agreement affix should be present on V before V-to-T/I (Alexiadou \& Anagnostopoulou 1998: 522 argue that strong agreement affixes are either merged with the verb in the internal domain, in which case they surface as affixes, or on $\mathrm{T}$, in which case they surface as clitics). In other words, the $[+\mathrm{D}]$ agreement affix of weather predicates cannot possibly be incorporated/merged onto the verb within VP (due to the Inclusiveness Condition). On the other hand, if it gets merged directly on T, then EPP would actually be satisfied by merge and not by head movement (in other words, in a fashion similar to the English expletive constructions, something that Alexiadou \& Anagnostopoulou 1998 convincingly argue against). 
TP], runs into problems of optionality, as such displacement does not take place in SV (section 3) orders, in VS (section 4) orders and in impersonal constructions in Greek. b) Its conception as a mere requirement for the presence of phonologically overt material (the [P]-feature) creates more problems than it solves, as Greek mainly manifests orders in which the pre-T position is empty (and, therefore, the postulation of vacuous movement operations is required if the existence of $\mathrm{EPP}_{\mathrm{T}}$ is taken for granted). c) Its conception as a parametrized requirement for the checking of $[\mathrm{D}]$ on $\mathrm{T}$ either via normal phrasal movement to $[$ Spec, $\mathrm{TP}]$ or via movement of $\mathrm{V}$, endowed with a $[\mathrm{D}]$ categorial feature, to $\mathrm{T}$, gives virtually indistinguishable results with the postulation of the suspension of $\mathrm{EPP}_{\mathrm{T}}$.

In view of the above complications, the proposal we would like to make is that the $\mathrm{EPP}_{\mathrm{T}}$-requirement is subject to parametric variation, i.e it is observed in non-pro-drop languages while it is not present in pro-drop ones. ${ }^{22}$ Under this formulation, no [Spec, TP] is projected in null subject languages. This is by no means a novel proposal, as it has been put forth by McCloskey (1997), ${ }^{23}$ while a number of recent studies argue for the elimination of $\mathrm{EPP}_{\mathrm{T}}$ altogether (Castillo, Drury \& Grohmann 1999; Epstein \& Seely 2006; Bošković 2007).

In fact, the existence of VS orders and the lack of expletives even in impersonal constructions in Greek, coupled with the anavailabilty of [Spec, TP] should point towards such a parameterization as the simplest account (the one that involves no unnecessary stipulations). In such a system, true subjects in Greek are $\nu$ P-internal elements which (when instantiated as pro) may be coindexed with peripheral material. Thus, the minimum structure of an unergative clause in Greek is the one in (47), while the minimum structure of an ergative one is the one in (48).

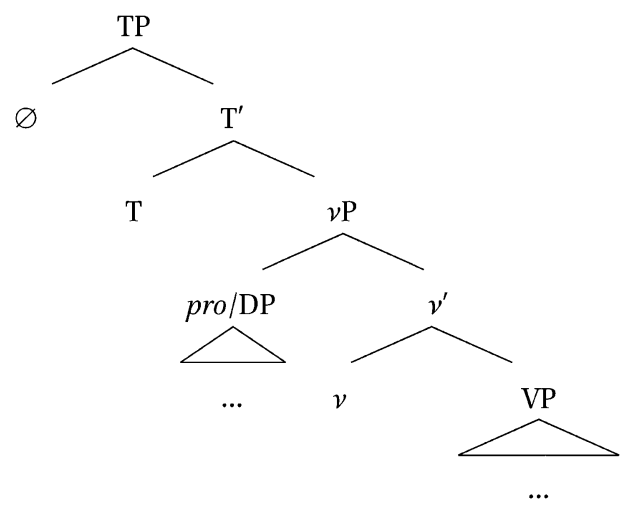

22) Cf. also Alexiadou \& Anagnostopoulou (1998), fn. 9.

23) See Kotzoglou (2001) for a first formulation of such a proposal concerning Greek subjects. 
$(48)$

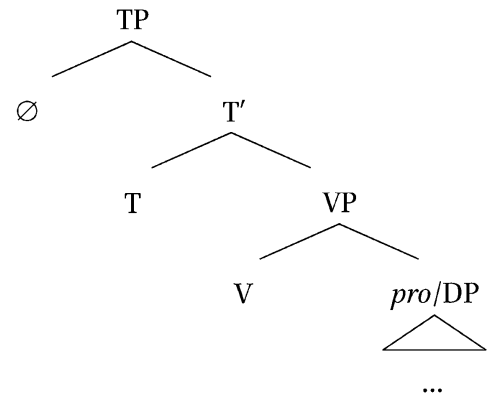

\section{Implications for Word Order}

To the extent that the simplicity of derivation is a factor distinguishing between 'basic' and 'marked' word orders (as argued for in Philippaki-Warburton 1985) the discussion so far leads to the conclusion that VSO is the basic word order in Greek, as it involves the minimum amount of syntactic operations or descriptive machinery. As argued for extensively, in Greek VSO both S and O occupy their base positions, while V-to-T movement is obligatory in all sentences. On the other hand, S-initial orders are more costly and, therefore, syntactically marked in two respects: a) they involve the base-generation of a phrase in a left-peripheral position and its coindexation with the $\nu \mathrm{P}$-internal subject, $\mathrm{b}$ ) they carry the extra interpretation associated with the surface position of the external subject. As discussed in the beginning of this paper, this was indeed the proposal advanced in a number of classic studies on Greek word order, such as Philippaki-Warburton $(1985,1987)$, Alexiadou (1999) etc. The role of the present article was to put the foundations of such analyses (namely, the unavailability of [Spec, TP] and the non-movement of S in inverted orders) under scrutiny, especially with respect to a number of recent works challenging them and under the light of recent developments in syntactic analysis.

\section{References}

Alexiadou, Artemis. 1999. On the Properties of Some Greek Word Order Patterns. In Artemis Alexiadou, Geoffrey Horrocks and Melita Stavrou (eds.), Studies in Greek Syntax, 45-65. Dordrecht: Kluwer Academic Publishers.

Alexiadou, Artemis. 1996. Subject Positions in Modern Greek. Studies in Greek Linguistics 16: 242253 .

Alexiadou, Artemis and Elena Anagnostopoulou, 1998. Parametrizing AGR: Word Order, V-Movement and EPP-Checking. Natural Language and Linguistic Theory 16: 491-539.

Alexiadou, Artemis and Elena Anagnostopoulou. 1999. EPP without Spec, IP. In David Adger, Susan Pintzuk, Bernadette Plunkett and George Tsoulas (eds.), Specifiers: Minimalist Approaches, 93-109. Oxford: Oxford University Press

Alexiadou, Artemis and Elena Anagnostopoulou. 2001. The Subject-in-Situ Generalization and the Role of Case in Driving Computations. Linguistic Inquiry 32: 193-231. 
Anagnostopoulou, Elena. 1994. Clitic dependencies in Modern Greek. Ph.D. Dissertation, University of Salzburg.

Belletti, Adriana. 2004. Aspects of the Low IP Area. In Luigi Rizzi (ed.), The Cartography of Syntactic Structures, Vol. 2: The Structure of CP and IP, 16-51. Oxford: Oxford University Press.

Bobaljik, Jonathan David. 2002. A-Chains at the PF Interface: Copies and 'Covert' Movement. Natural Language and Linguistic Theory 20: 197-267.

Boeckx, Cedric. 2003. Islands and Chains: Resumption as Stranding. Amsterdam: John Benjamins Publishing Company.

Boeckx, Cedric. 2008. Bare Syntax. Oxford: Oxford University Press.

Bošković, Željko. 2001. On the Nature of the Syntax-Phonology Interface: Cliticization and Related Phenomena. Amsterdam: Elsevier.

Bošković, Željko. 2004. On the Clitic Switch in Greek Imperatives. In Olga Mišeska (ed.), Balkan Syntax and Semantics, 269-291. Amsterdam: John Benjamins Publishing Company.

Bošković, Željko. 2007. On the Locality and Motivation of Move and Agree: An Even More Minimal Theory. Linguistic Inquiry 37: 589-644.

Brandi, Luciana and Patrizia Cordin. 1989. Two Italian Dialects and the Null-Subject Parameter. In Osvaldo Jaeggli and Ken J. Safir (eds.), The Null Subject Parameter, 111-142. Dordrecht: Kluwer Academic Publishers.

Carlson, Greg. 1977. Reference to kinds in English. Ph.D. Dissertation, University of Massachusetts at Amherst.

Castillo, Juan Carlos, John Drury and Kleanthes K. Grohmann. 1999. Merge over Move and the Extended Projection Principle. University of Maryland Working Papers in Linguistics 8: 63-103.

Chomsky, Noam. 1981. Lectures on Government and Binding: The Pisa Lectures. Berlin: Mouton de Gruyter.

Chomsky, Noam. 1994. Bare Phrase Structure. MIT Occasional Papers in Linguistics 5.

Chomsky, Noam 1995. The Minimalist Program. Cambridge, Massachusetts: MIT Press.

Chomsky, Noam. 2000. Minimalist Inquiries: The Framework. In Roger Martin, David Michael and Juan Uriagereka (eds.), Step by Step: Essays on Minimalist Syntax in Honor of Howard Lasnik, 89-155. Cambridge, Massachusetts: MIT Press.

Chomsky, Noam. 2001. Derivation by Phase. In Michael Kenstowicz (ed.), Ken Hale: A Life in Language, ${ }^{-}-5$ 2. Cambridge, Massachusetts: MIT Press.

Chomsky, Noam. 2008. On Phases. In Jean-Roger Vergnaud, Robert Freidin, Carlos Otero and Maria Luisa Zubizarreta (eds.), Foundational Issues in Linguistic Theory: Essays in Honor ofJean-Roger Vergnaud, 133-166. Cambridge, Massachusetts: MIT Press.

Diesing, Molly. 1992. Indefinites. Cambridge, Massachusetts: MIT Press.

Drachman, Gaberell. 1985. Language Universals: The Two Approaches. In Ursula Pieper and Gerhard Stickel (eds.), Studia Linguistica Diachronica et Synchronica, 175-201. Berlin: Mouton de Gruyter.

Drachman, Gaberell and Chryssoula Klidi. 1992. The Extended Minimal Structure Hypothesis. Studies in Greek Linguistics 13: 371-389.

Epstein, Samuel David and T. Daniel Seely. 2006. Derivations in Minimalism. Cambridge: Cambridge University Press.

Georgiafentis, Michalis. 2001. On the Properties of the VOS Order in Greek. Reading Working Papers in Linguistics 5: 137-154.

Georgiafentis, Michalis. 2004. Focus and word order variation in Greek. Ph.D. Dissertation, The University of Reading.

Greenberg, Joseph Harold. 1963. Some Universals of Grammar with Particular Reference to the Order of Meaningful Elements. In Joseph Harold Greenberg (ed.), Universals of Language, 73-113. Cambridge, Massachusetts: MIT Press.

Holmberg, Anders. 2000. Scandinavian Stylistic Fronting: How Any Category can Become an Expletive. Linguistic Inquiry 31: 445-483. 
Holmberg, Anders and Thorbjörg Hróarsdóttir. 2003. Agreement and Movement in Icelandic Raising Constructions. Lingua 113: 997-1019.

Hornstein, Norbert. 2001. Move! A Minimalist Theory of Construal. Oxford: Blackwell Publishers.

Horrocks, Geoffrey. 1994. Subjects and Configurationality: Modern Greek Clause Structure.Journal of Linguistics 30: 80-109.

Johnson, Kyle and Satoshi Tomioka. 1998. Lowering and Mid-size Clauses. Paper presented at the 1997 Tübingen workshop on reconstruction.

Keller, Frank and Theodora Alexopoulou. 2001. Phonology Competes with Syntax: Experimental Evidence for the Interaction of Word Order Placement in the Realization of Information. $\operatorname{cog}$ nition 79: 301-372.

Kotzoglou, George. 2001. First Notes on Greek Subjects. Reading Working Papers in Linguistics 5: 175-199.

Kotzoglou, George. 2005. Wh-extraction and locality in Greek. Ph.D. Dissertation, The University of Reading.

Kotzoglou, George. 2006. Subject-Verb Inversion in Greek: Implications for Head-Movement and Typology. Journal of Universal Language 7: 91-137.

Kotzoglou, George. 2010. (Non-)Extraction from Subjects as an Edge Phenomenon. In Phoevos Panagiotidis (ed.), The Complementizer Phase: Subjects and Operators, 33-50. Oxford: Oxford University Press.

Landau, Idan. 2007. EPP Extensions. Linguistic Inquiry 38: 485-523.

Lascaratou, Chryssoula. 1989. A Functional Approach to Constituent Order with Particular Reference to Modern Greek: Implications for Language Learning and Language Teaching. Athens: Parousia Journal Monograph Series 5 .

Lascaratou, Chryssoula. 1994. Performance Principles of Word Order Variation. Athens: Parousia Journal Monograph Series 29.

Lascaratou, Chryssoula. 1998. Basic Characteristics of Modern Greek Word Order. In Anna Siewierska (ed.), Constituent Order in the Languages of Europe, 151-171. Berlin: Mouton de Gruyter.

Lascaratou, Chryssoula and Michalis Georgiafentis. 2006. Vasika Xaraktiristika tis Siras ton Protasiakon Oron stin Eliniki kai stin Turkiki (Basic Characteristics of Word Order in Greek and

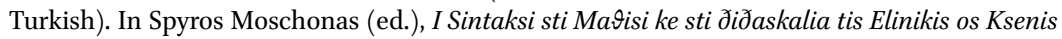
ylosas (Syntax in Learning and Teaching of Greek as a Foreign Language), 11-61. Athens: Patakis.

Lebeaux, David. 2000. Language Acquisition and the Form of Grammar. Amsterdam: John Benjamins Publishing Company.

Lebeaux, David. 2009. Where Does Binding Theory Apply? Cambridge, Massachusetts: MIT Press.

Mavrogiorgos, Marios. 2009. Proclisis and enclisis in Greek. Ph.D. Dissertation, University of Cambridge.

McCloskey, James. 1997. Subjecthood and Subject Positions. In Liliane Haegeman (ed.), Elements of Grammar: Handbook of Generative Syntax, 197-235. Dordrecht: Kluwer Academic Publishers.

Nunes, Jairo. 1999. Linearization of Chains and Phonetic Realization of Chain Links. In Samuel David Epstein and Norbert Hornstein (eds.), Working Minimalism, 217-249. Cambridge, Massachusetts: MIT Press.

Panagiotidis, Phoevos. 2002. Pronouns, Clitics and Empty Nouns: 'Pronominality' and Licensing in Syntax. Amsterdam: John Benjamins Publishing Company.

Panagiotidis, Phoevos and Stavroula Tsiplakou. 2006. An A-Binding Asymmetry in Null Subject Languages and Its Significance for Universal Grammar. Linguistic Inquiry 37: 167-177.

(Philippaki-)Warburton, Irene. 1975. The Passive in English and Greek. Foundations of Language 13: 563-578.

Philippaki-Warburton, Irene. 1982. I Simasia tis Siras Rima Ipokimeno Andikimeno sta Nea Elinika (The Importance of the Verb Subject Object Order in Modern Greek). Studies in Greek Linguistics 3: 113-143. 
Philippaki-Warburton, Irene. 1985. Word Order in Modern Greek. Transactions of the Philological Society: 113-143.

Philippaki-Warburton, Irene. 1987. The Theory of Empty Categories and the Pro-Drop Parameter in Modern Greek. Journal of Linguistics 23: 289-318.

Philippaki-Warburton, Irene. 1989. 'Subject' in English and Greek. Proceedings of the 3rd Symposium on the Description and/or Comparison of English and Greek, 11-32. Thessaloniki: Aristotle University, School of English.

Philippaki-Warburton, Irene. 1998. Functional Categories and Modern Greek Syntax. The Linguistic Review 15: 159-186.

Philippaki-Warburton, Irene. 2001. Glosolojiki @eoria ke Sindaksi tis Elinikis: I Pikilia sti Sira ton Oron ke i Erminia tis (Linguistic Theory and Greek Syntax: Word Order Variation and its Interpretation). In Georgia Agouraki et al. (eds.), Greek Linguistics '99: Proceedings of the 4th International Conference on Greek Linguistics, 217-231. Thessaloniki: University Studio Press.

Philippaki-Warburton, Irene and Vassilios Spyropoulos. 1999. On the Boundaries of Inflection and Syntax: Greek Pronominal Clitics and Particles. In Gert Booij and Jaap van Marle (eds.), The Yearbook of Morphology 1998, 45-72. Dordrecht: Kluwer Academic Publishers.

Philippaki-Warburton, Irene, Spyridoula Varlokosta, Michalis Georgiafentis and George Kotzoglou. 2004. Moving from Theta-Positions: Pronominal Clitic Doubling in Greek. Lingua 114: 963989 .

Richards, Marc D. 2007. On Feature Inheritance: An Argument from the Phase Impenetrability Condition. Linguistic Inquiry 38: 563-572.

Richards, Norvin. 2001. Movement in Language: Interactions and Architectures. Oxford: Oxford University Press.

Richards, Norvin. 2006. A Distinctness Condition on Linearization. Ms. MIT.

Rivero, María Luisa. 1994. Clause Structure and V-Movement in the Languages of the Balkans. Natural Language and Linguistic Theory 12: 63-120.

Rivero, María Luisa and Arhonto Terzi. 1995. Imperatives, V-Movement and Logical Mood.Journal of Linguistics 31: 301-332.

Rizzi, Luigi. 1982. Issues in Italian Syntax. Dordrecht: Foris Publications.

Rizzi, Luigi. 1990. Relativized Minimality. Cambridge, Massachusetts: MIT Press.

Rizzi, Luigi. 1997. The Fine Structure of the Left Periphery. In Liliane Haegeman (ed.), Elements of Grammar: Handbook of Generative Syntax, 281-337. Dordrecht: Kluwer Academic Publishers.

Rizzi, Luigi. 2001. Relativized Minimality Effects. In Martin Baltin and Chris Collins (eds.), The Handbook of Contemporary Syntactic Theory, 89-110. Oxford: Blackwell Publishers.

Rosenbaum, Peter S. 1970. A Principle Governing Deletion in English Sentential Complementations. In Roderick A. Jacobs and Peter S. Rosenbaum (eds.), Readings in English Transformational Grammar, 20-29. Waltham, Massachusetts: Ginn.

Roussou, Anna. 2000. On the Left Periphery: Modal Particles and Complementisers. Journal of Greek Linguistics 1: 65-94.

Roussou, Anna and Ianthi-Maria Tsimpli. 2006. On Greek VSO Again! Journal of Linguistics 42: 317-354.

Safir, Kenneth J.1982. Syntactic chains and the definiteness effect. Ph.D. Dissertation, Massachusetts Institute of Technology.

Safir, Kenneth J. 1987. What Explains the Definiteness Effect? In Eric J. Reuland and Alice G.B. ter Meulen (eds.), The Representation of (In)definiteness, 71-97. Cambridge, Massachusetts: MIT Press.

Sifaki, Evi 2003. EPP-satisfiers: verb-initial orders in Greek. Ph.D. Dissertation, University of York.

Sifaki, Evi. 2004. The EPP Requirement. York Papers in Linguistics 1: 181-212.

Sifaki, Evi and Ioanna Sitaridou. 2007. EPP Revisited: Evidence from Null Subject Languages. In Eleni Agathopoulou, Maria Dimitrakopoulou and Despina Papadopoulou (eds.), 17th Interna- 
tional Symposium: Selected Papers on Theoretical and Applied Linguistics, 177-198. Thessaloniki: Monochromia Publishing.

Sportiche, Dominique. 1999. Pronominal Clitic Dependencies. In Henk van Riemsdijk (ed.), Clitics in the Languages of Europe, 679-708. Berlin: Mouton de Gruyter.

Spyropoulos, Vassilios. 1999. Agreement relations in Greek. Ph.D. Dissertation, The University of Reading.

Spyropoulos, Vassilios and Anthi Revithiadou. 2007. Subject Chains in Greek and PF Processing. Ms., LingBuzz [http://ling.auf.net/lingBuzz/oo0497] (15/3/2011)

Spyropoulos, Vassilios and Anthi Revithiadou. 2009. Subject Chains in Greek and PF Processing. MIT Working Papers in Linguistics 57: 293-309.

Spyropoulos, Vassilios and Irene Philippaki-Warburton. 2001. 'Subject' and EPP in Greek: The Discontinuous Subject Hypothesis. Journal of Greek Linguistics 2: 149-186.

Stepanov, Arthur Vladimirovich. 2001. Cyclic domains in syntactic theory. Ph.D. Dissertation, University of Connecticut.

Takahashi, Daiko. 1994. Minimality of movement. Ph.D. Dissertation, University of Connecticut.

Tsimpli, Ianthi-Maria. 199o. The Clause Structure and Word Order of Modern Greek. UCL Working Papers in Linguistics 2: 226-255.

Tsimpli, Ianthi-Maria. 1995. Focusing in Modern Greek. In Katalin É. Kiss (ed.), Discourse Configurational Languages, 176-206. Oxford: Oxford University Press.

Tsiplakou, Stavroula. 1998. Focus in Greek: its structure and interpretation. Ph.D. Dissertation, University of London.

Tsiplakou, Stavroula. 1999. I Đomi tis Protasis tis Neas Elinikis: Mia Prosengisi sta Plesia tu Protipu Labelled Deductive Systems (Modern Greek Sentence Structure: An Approach within the Labelled Deductive Systems Framework). In Amalia Moser (ed.) Greek Linguistics '97: Proceedings of the 3rd International Conference in Greek Linguistics. 284-293. Athens: Ellinika Grammata.

Tzanidaki, Dimitra Irini. 1995. Greek Word Order: Towards a New Approach. UCL Working Papers in Linguistics 7: 247-277.

Zubizarreta, Maria Luisa. 2001. The Constraint on Preverbal Subjects in Romance Interrogatives: A Minimality Effect. In Aafke C.J. Hulk and Jean-Yves Pollock (eds.), Subject Inversion in Romance and the Theory of Universal Grammar, 183-204. Oxford: Oxford University Press. 